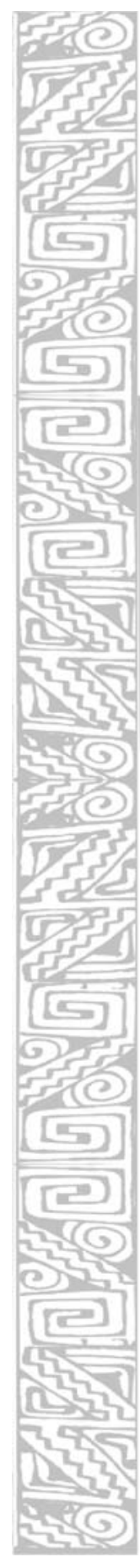

\title{
Filosofia, antropologia: \\ o fim de um mal-entendido ${ }^{1}$
}

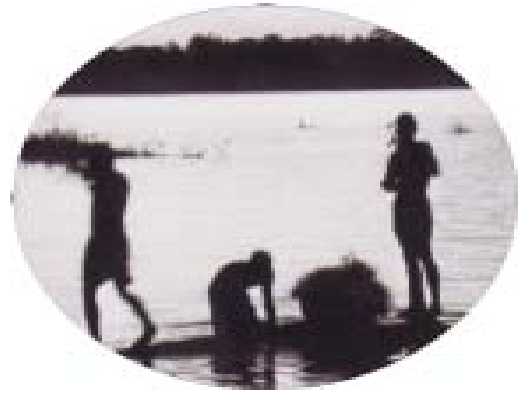

Claude Imbert ${ }^{2}$

Resumo

$\mathrm{O}$ artigo analisa a relação entre filosofia e ciências humanas e como esse processo ocorreu historicamente desde a herança kantiana, passando por Durkheim, Lévi-Strauss, concentrando-se especialmente em Merleau-Ponty.

\section{Palavras-chave}

Filosofia; fenomenologia; sociologia; ciência.

\section{Abstract}

The article analyses the relationship between philosophy and human sciences. And, as this process had happened historically since

${ }^{1}$ Tradução de Nelson Matos de Noronha, Doutor em Filosofia, professor do Departamento de Filosofia e do Programa de Pós-Graduação em Sociedade e Cultura na Amazônia da Universidade Federal do Amazonas. Revisão Técnica de Lileaneane Praia Portela de Aguiar, Mestranda do Programa de Pós-Graduação em Sociedade e Cultura na Amazônia da Universidade Federal do Amazonas, Professora da Faculdade Objetivo. Professora de Filosofia da École Normale Supérieure de Paris; professora associada da Universidade da Califórnia; professora associada da Universidade John Hopkins; Felow da Getty Foundation, Santa Mônica; autora de Phénomenoligies et langues formulaires. PUF, 1992, e da tradução francesa dos Ecrits logiques et philosophiques, de G. Frege. 
Kant, Durckheim, Levi-Strauss, the acme of the deeds was especially pointed out in Mereau-Ponty.

Keywords

Philosophy; phenomenology; sociology; science.

Desde o meio do século, filosofia e ciências humanas institucionalizaram suas relações. Uma mesma rubrica as reuniu nas classificações da Unesco. No seio da universidade francesa, o conflito havia sido rude. O que não impede que, em algumas décadas, a rivalidade tenha cedido à aceitação. Uma cadeira de sociologia foi criada por Émile Durkheim em 1913. O Instituto de Etnologia, confiado a Marcel Mauss e a Lucien Lévy-Bruhl, o foi em 1929, precedendo de pouco a abertura do Museu do Homem. A partir da guerra, a fundação da Maison des sciences de l'homme [Casa das Ciências do Homem], a independência adquirida pela École des hautes études en sciences sociales [Escola de Altos Estudos em Ciências Sociais] e o lugar hoje concedido à filosofia confirmaram a aliança cordial das disciplinas. Vista pelo lado das ciências humanas, essa história já está escrita. ${ }^{3}$ Resta considerar aquilo de que este breve quadro institucional nada disse ainda, isto é, uma seqüência de acontecimentos internos à filosofia onde sua identidade esteve em jogo. Não esqueçamos que houve enxameamento. Durkheim, Lévy-Bruhl e Mauss eram filósofos de formação. Isso também foi verdade para Raymond Aron, Jean Pierre Vernant e Claude Lévi-Strauss, e verifica-se ainda na geração seguinte. O mesmo ocorreu na Alemanha, onde Ernst Cassirer, publicando Individuum und Cosmos em 1927 na Biblioteca Warburg, deu o exemplo.

Ora, qualquer que tenha sido a distância tomada em relação à primeira disciplina, a ruptura ainda está bem distante de ser facilmente assinalável. Para cada

${ }_{3}^{3}$ Por exemplo, Wolf Lepenies, Les trois cultures: entre science et littératture, l'avènement de la sociologie, 1990, et, Giuliana Gemelli, Fernand Braudel, préf. De Maurice Aymard, 1995.

204 Somanlu, ano 3, n. 1/2, jan./dez. 2003 
um desses trânsfugas, assim como para as disciplinas que eles abriram, as coisas se passaram de forma bem diferente daquilo que se sucedeu no caso das ciências exatas. Aqui, a independência da física foi consumada com Galileu, a das matemáticas, com d'Alembert e Gauss. Ali, as fronteiras permaneceram móveis: entre um saber e um outro, entre todos eles e a filosofia. A filosofia das formas simbólicas, de Ernst Cassirer, caucionaria, por muito tempo, uma transação de dupla entrada à qual ninguém renunciava. Resta compreender o porquê e o como dessa situação de fato. Diminutio capitis ${ }^{4}$ para muitos, ou salutar conseqüência da extensão de um saber para a qual a filosofia clássica não tinha rubrica? Isso ainda está em disputa. Mas não mais a partilha dos domínios, tão evidente que nem mesmo a destituição hierárquica toca no essencial. Trata-se aqui de uma prova em que a atividade filosófica se encontrava confrontada com o seu exterior (dehors), com sua própria história e com sua operação. ${ }^{5}$

Colocar-nos-emos, portanto, deliberadamente ao lado de uma filosofia do pós-guerra, que não cedia em face dessas ciências humanas que, da história à sociologia, cruzavam seu propósito e partilhavam muitas de suas incertezas. $\mathrm{E}$ uma vez que Sartre e Merleau-Ponty arbitraram em sentido inverso, é preciso pensar que aí se passou alguma coisa de essencial para a filosofia contemporânea. O primeiro apóia sua Crítica da razão dialética. Para ele, a antropologia vinha em continuidade com a história, como fundo de quadro da literatura. Mas Sartre em nada cedia da trama filosófica que lhe dá sentido: o homem-sujeito. A situação dá à experiência sua variante dialética e concreta. Da literatura que ele faz ou que lê, de A portas fechadas aos Caminhos da liberdade, de Faulkner a Mallarmé, de Que é a literatura? a O idiota da família, Sartre reitera a questão de possibilidade dos Tempos modernos: da coisa, ela mesma, da escritura que dela circunscreveu o desafio e da revista que dela conduzia o debate. E isto para afrontar a memória de duas guerras, a perspectiva de uma outra, a ausência de visão da filosofia sobre a atualidade social e política, e o niilismo que elas destilam. Ele opunha ao buis clos filosófico à

\footnotetext{
${ }^{4}$ Nota do tradutor: o Dicionário Barsa da Língua Portuguesa llustrado (v. 2 Jabá-Zuzá, Cia. Melhoramentos de São Paulo, 1980, p. 1330) fornece-nos o seguinte sentido da expressão capitis diminutio: Dir. Diminuição de capacidade. Empregada para designar a perda da autoridade.

${ }^{5}$ Cf. Maurice Merleau-Ponty, Signes, chap. V: "Partout et nulle part, la Philosophie et le dehors".

${ }^{6}$ N. T. Da expressão jurídica "à huis clos" (a portas fechadas).
} 
segurança solipsista de que "o inferno são os outros", esse humanismo renovado que ele chama ocasionalmente de antropologia. Isto quer dizer que a antropologia pode, por ela mesma, ser filosofia? À sua própria questão, Sartre responde que o homem da antropologia é objeto, o homem da filosofia, objeto-sujeito. E isto sem jamais cessar de dar sua confiança à história nem de delegar a expressão desta à criação literária. A Crítica da raz̃ão dialética corrigia, portanto, o jogo do tudo ou nada, da consciência absoluta e de sua liquidação, no qual Sartre havia engajado vinte anos mais cedo sua carreira filosófica ${ }^{7}$. Ela não o mudará.

Nos mesmos anos cinqüenta, Merleau-Ponty já havia esgotado todas as maneiras concebíveis de forçar o estreitamento de uma conceptualidade filosófica fixada pelas condições kantianas da experiência. A estrutura do comportamento fixava a instância filosófica na instabilidade [mowvance] de uma série de comportamentos dos quais ela se encarregaria, em seguida, de substituir. Quanto à Fenomenologia da percep̧ãa, ela desenvolvia o momento perceptivo a partir de suas preliminares psicofisiológicas até, para além dela, a existência na história. Mas, tendo escolhido uma descrição fenomenológica para seu acesso ao concreto, Merleau-Ponty se encontrava preso à armadilha de uma estrutura de coisa e de fato que nenhuma significação poderia dissolver, que nenhum apelo à literatura, à pintura ou aos enquadramentos surrealistas poderia transgredir. Primeiro fracasso no ensaio de uma dialética concreta onde Husserl teria completado Hegel e todas as fenomenologias uniriam seus esforços. Um pouco mais tarde, ser-lhe-á necessário reconhecer que "a dialética está em pane". Restava-lhe abandonar uma história fechada, recomendando nela jogar-se o olhar "ingênuo" do antropólogo [...]

Sartre e Merleau-Ponty estavam, portanto, igualmente convencidos, até em seus desacordos políticos, da não efetividade [ineffectivité de uma maneira filosófica que eles já haviam, um e outro, tirado de seus gonzos. Entretanto, Sartre perseverará, do interior de uma filosofia do sujeito, [ainda que] tivesse [para tanto] de emprestar as vias do teatro, do editorial político e da literatura. Merleau-Ponty, por sua parte, desvia-se das fórmulas da existência e se interroga sobre a possibilidade mesma da filosofia. Ele havia abandonado o projeto de uma Prosa

7 Cf. Entrevista dada após a publicação da Crítica da razão dialética.

206 Somanlu, ano 3, n. 1/2, jan./dez. 2003 
do mundo e desacreditava da ação. De fato, ele abria uma outra história e a engajava no que ele chamará, em suas últimas notas e retomando uma fórmula de Cavaillès, algumas amostras de pensamento fundamental ${ }^{8}$. Tratava-se de uma teoria da expressão da qual depende toda consciência filosófica. Ela seria, desta vez, diversificada segundo seus suportes e suas intenções. Tendo o criticismo saturado sua capacidade de realismo, esgotado sua tábua das categorias em uma experiência fechada sobre fórmulas "newtonianas" privadas de futuro, era preciso recolocar em movimento a empresa filosófica e recusar a uma analítica a imposição de seus direitos plenos sobre todas as outras. É aqui que se fez o encontro com LéviStrauss. Aqui se confirmava que era possível evitar o criticismo e desatar seus nós. Doravante a antropologia dos filósofos terá cessado de ser um chavão. "Hegel, dizia Merleau-Ponty no momento em que tomava sua última licença, jamais escolheu entre a antropologia e a lógica". Dito em uma frase, era um olhar jogado sobre sua própria história e a confissão de sua própria renúncia à ilusão de uma dialética concreta.

Nós estaríamos, então, reduzidos aos limites da questão se, em meados do século, a etnografia não houvesse, ela mesma, redefinido seu realismo e atravessado o obstáculo que se lhe opõem as condições kantianas da experiência. Merleau-Ponty havia reconhecido aí o sentido de um debate conduzido entre dois etnólogos de rostos filosóficos e kantianos de formação. O encontro se fez, portanto, sobre algumas questões, elas mesmas banais - natureza e cultura, a modernidade, a crise do saber, a subjetividade, a troca -, mas sobre as quais a filosofia, de par com sua natureza própria, precisamente não possuía outras abordagens além de suas distantes e por vezes queixosas maneiras de dizer. Ao passo que entre Mauss e Lévi-Strauss se havia preparado uma saída que MerleauPonty foi incontestavelmente o primeiro a perceber. Desejar-se-ia relembrar esse diálogo em termos pelos quais se declarará abertamente nossa dívida para com seus protagonistas. Porque nos dois casos tratava-se de sair honradamente de uma metodologia kantiana, de romper um limite no momento em que a urgência era sublinhada por uma falha histórica.

${ }_{8}^{8}$ Maurice Merleau-Ponty, Notes de cours, 1959-1961, p. 166/391. 
Filosofia, antropologia:

o fim de um mal-entendido

A possibilidade da etnografia

Durkheim ${ }^{9}$ constituíra sua disciplina no rastro de Comte. Ele empenhavase, então, para fazer progredir a sociologia em uma escala definida entre a idade teológica e a idade positiva. Tanto que $A$ s regras do método sociológico ensinam a tratar os fatos sociais como coisas. Mas a matéria e a ocasião de sua dissidência filosófica não se formam tão graciosamente. A divisão do trabalho social, depois $O$ suicídio, ou $A$ s formas elementares da vida religiosa, que afrontavam a questão moderna da integração social, deviam vir a tratar de algumas dinâmicas sociais e de sua interiorização. Uma abordagem [approche] positivista de tais fenômenos, como coisa e como fato, não tardava a tocar seu limite. Por mais novos e convincentes que tenham sido os quadros estatísticos e as classificações, eles já eram absolutamente outra coisa que fatos de experiência. Eles não carregavam como sua conseqüência a explicação que lhes dava Durkheim. O cuidado da informação e da objetividade empurrava a análise em direção a fatos que subitamente tomavam a forma de instituições. Por seu turno, e como a dialética, o positivismo tornava-se um chavão e uma espécie [manière] de ponto de honra. De fato, As formas elementares da vida religiosa remetiam ao totemismo australiano.

Fenômenos incontestavelmente sociais, pensados, conceptualizados e objetivados em uma escala social solicitavam, de início, uma reflexão sobre a conceptualidade adequada. Eles pediam uma abordagem [approche] endógena das categorias religiosas: daí uma outra metodologia. Todavia, Durkheim preservava o esquema geral da experiência. Ele supõe uma coletividade-sujeito, postula representações coletivas e esboça uma lógica que recolheria a pregnância [pregnance] do social. Daí esse ensaio, Sobre algumas formas primitivas de classificaşão, do qual Needham pôde dizer que ele pressupõe a questão ${ }^{10}$. Tocava-se no esgotamento de um método criticista, reconduzindo a experiência a suas condições de possibilidade. Não se tratava de uma demissão em favor do arcaico ou do pré-lógico, portanto, do que foi necessário pensar como o impensável, mas de objetivar simultaneamente uma realidade

${ }^{9} \mathrm{Cf}$. Claude Lévi-Struass, La sociologie française in Socilogie au xxe siècle.

${ }^{10}$ Needham, Préface à la traduction anglaise. L'essai du à la collaboration de Mauss et Durkheim avit été publié en 1903 avec le sous-titre: Contribution à l'étude des représentatttions collectives. 
e as maneiras de pensá-la. Uma tal empresa, que não poderia renegar o criticismo, não era menos intrusa em uma economia de juízo transcendental onde a variação das opções simbólicas é precisamente o que é excluído. Restava-lhe fazer valer suas razões.

Desde então, ao mesmo tempo em que a sociologia se tornaria o conhecimento empírico que ela desejava ser e no qual se torna efetivamente, ela teria de assumir como uma parte dela mesma o que lhe provinha das questões ligadas à sua própria dissidência filosófica. Porque o domínio que ela se atribuía desconcertava o método e a epistemologia dos fatos e das coisas. Era necessário repensar a experiência, em vista da conjunção de fenômenos ainda não percebidos e de sua inteligibilidade. Faltava conceber uma alternativa a Kant, mas que estivesse à altura do criticismo.

Após Durkheim, a mesma demanda permanecia. Desta vez, ela se encontrava ligada à experiência de campo. O desafio não era o de uma comunicação com o extremo exótico, que, verossimilmente, continuava ausente - todo etnógrafo tendo experimentado essa decepção que Leiris descreve, da mesma forma que o fazem Malinowski e alguns episódios narrados por Lévi-Strauss ${ }^{11}$. Tratava-se da possibilidade de a etnografia nesse momento de uma história européia que a primeira guerra havia desembriagado do colonialismo, talvez mesmo de sua necessidade quando esta história fragmentava-se em reivindicações e ressentimentos. A questão subjaz aos escritos de Mauss, atravessa os últimos Cadernos de Lévy-Bruhl e faz de Tristes trópicos um grande livro de filosofia. A prova da descrição etnográfica, e o Manual de Mauss que a fornece, haviam atuado tal como um revelador. Uma factualidade, da qual em vão se solicitava as coordenadas da experiência, transformara-se em double-bind do etnógrafo. Não porque o racionalismo barrasse o vivido e a intuição, mas porque ele não estava à altura de suas ambições. Todo um passado de descrição, vindo de Heródoto, de Estrabão e de Boungainville provava de sua própria cegueira. Alguma coisa escapava a uma experiência forjada e endurecida ao fogo do criticismo e que não era da ordem do conhecimento do outro - questão interna à filosofia - nem da dificuldade de acolher o estrangeiro, esta aqui interna à ética ou à vida civil. A filosofia

${ }^{11} \mathrm{Cf}$. Afrique fantôme de Leiris, Les carnets, de Malinowski e Tristes tropiques. 
descobria subitamente sua tarefa cega, uma operação que ela não podia conceber. Confrontada a condutas e instituições que desdenhavam a descrição, Mauss fazia ver um exterior [dehors] inscrito no mais íntimo de nós mesmos. Ele solicitava uma possibilidade de pensar que devia ser nossa de uma certa maneira, mas que precisava ser retirada de suas manifestações opacas. Esse desafio pedia por uma abordagem [approche] indireta de nós mesmos. Esses filósofos trânsfugas experimentavam simultaneamente o buis $\operatorname{clos}^{12}$ da filosofia, do qual eles tinham fugido, e o exterior desse huis $\cos ^{13}$. Mas nenhum deles renunciava a compreender, isto é, a um postulado de humanidade acompanhado de todos os seus possíveis.

\section{Antropologia e subjetividade: a herança kantiana}

Esse conhecimento antropológico subitamente preso em uma dobra aporética revelava uma situação virtualmente imposta por Kant. Com efeito, Kant havia atribuído dois lugares à antropologia. Houve, primeiro, seu ensinamento popular, publicado como Antropologia do ponto de vista pragmático. No mesmo gênero, um ensinamento introdutório e popular, o Curso de lógica, enumera as questões filosóficas legítimas: “Que posso conhecer?”, “Que posso esperar?”, "Que devo fazer?”. As quais dependem, acrescenta Kant, de uma quarta: “Que é o homem?”. Mas Kant exclui finalmente esta ordem. A esta quarta questão, jamais tratada como tal, as três Críticas, que haviam assumido o encargo das três primeiras, teriam, portanto, respondido implicitamente: o homem é apenas seu ponto de encontro, aí ele encontra sua definição. As três Críticas são, de resto, organizadas sobre o paradigma do juízo. Sua tábua lógica é o emblema efetivo de uma subjetividade humana pelo resto perdida nas profundezas do Gemüth (do "espírito"): aí onde o natural do homem e as condições transcendentais do pensamento enquanto experiência mantém seu enigmático comércio. Seguindo uma observação incidente da primeira Crítica, o homem seria definitivamente um fenômeno para o homem - deve-se compreender que seria passível de um conhecimento circunscrito pelos princípios da experiência?

${ }^{12}$ N. T.: em itálico, em francês, no texto.

${ }^{13}$ Idem.

210 Somanlu, ano 3, n. 1/2, jan./dez. 2003 
Mas essa antropologia positiva jamais foi escrita. O homem de Kant se esgota entre seu segredo transcendental e o protocolo das três Críticas, compreendendo-se aí o que cada uma delas tolera em suas implicações - uma tendência natural às ilusões dialéticas, eventualmente algum gênio, e sempre a escolha do mal. Ele experimentará a lei moral como aflição e obrigação.

Antropologia pragmática e Crítica da rąão pura estariam, pois, definitivamente disjuntas, se Kant não houvesse, por duas vezes, indicado sua ligação. De início, o curso publicado destaca um momento decisivo na aprendizagem da linguagem, aquele em que a criança adquire o uso da primeira pessoa. ${ }^{14}$ Esse progresso, do qual ela jamais retrocederá, também é o acesso à terceira pessoa ${ }^{15}$ da experiência. Do mesmo modo, é o brutal surgimento da razão na história individual. Comparativamente, o Prefácio à segunda edição da primeira Crítica traça a linha de um gênio transcendental que escalona na história da humanidade uma série de conceptualidades. Essas etapas fragmentam e preparam a revolução copernicana em filosofia. A cada vez a experiência se enriquece com uma nova determinação. Mas todos, Tales, Galileu e alguns outros, operam na envergadura ou forma de uma operação descoberta por Aristóteles e que ergue, no corpo da obra, a tábua anônima das funções lógicas. A posse do "eu digo" [je dis] da antropologia pragmática está inscrita, portanto, no "eu penso" [jepense] transcendental. A primeira pessoa continua a operar tacitamente em cada um de nossos juízos. O positivismo do fato é uma enunciação assumida. A Antropologia Pragmática recolhia em um processo de educação uma manifestação da subjetividade transcendental. A Crítica se desenvolve justamente para além [de tal manifestação], na tábua das funções lógicas do eu penso [jepense]. O mesmo fato decidirá sobre a resposta à questão "Que são as Luzes?". São, para Kant, a maturidade da razão manifestada pela tomada em mãos de suas própria operações. A enigmática tábua lógica recolhia então, de fato, toda uma fenomenologia do espírito.

Mauss também esboçou uma gênese da subjetividade filosófica moderna, mas esquivando-se do transcendentalismo. Uma conferência tardia e como que

${ }^{14}$ Grifo do autor.

15 Idem.

Somanlu, ano 3, n. 1/2, jan./dez. 2003211 
testamentária, Uma categoria do espirito bumano: a noção de pessoa, a do 'eu' [moi] (1938), destaca o momento essencial em que, em Roma, o estoicismo encontrara um ritual etrusco: uma cerimônia funerária com máscaras. Uma vez amarradas a função social da máscara e a consciência moral no direito pessoal romano, Mauss segue uma linha que conduz a Kant e a Fichte. A hipótese, esboçada por toques disjuntos, tem em seu favor a evidente permanência do estoicismo lógico e do jurisdicismo romano até no vocabulário da Crítica kantiana. Ela torna-se ainda mais equívoca em suas implicações. Dever-se-ia concluir que a filosofia estava presa em uma história que não seria a sua? Ou bem essa história traçada retrospectivamente devolvia, no fim das contas, a substância da antropologia social à filosofia? Ou, ainda, Mauss explicitava uma hipótese que havia tacitamente acompanhado seu Ensaio sobre o dom, de dez anos antes, a de uma consciência moderna já engajada no officium jurídico da troca, e que devia solicitar a ela mesma desvelando um novo transcendentalismo? Aí se fazia valer um encontro onde poderíamos, com efeito, reconhecer a moral kantiana da escola francesa de sociologia, em nome da qual ele pretendeu falar, nas cercanias da Segunda Guerra, diante de um público de antropólogos ingleses.

Quanto à intenção filosófica do Ensaio, se o dom é mesmo um fato social do gênero que visavam as Regras do método sociológico, Mauss o havia arrancado à sua dispersão geográfica ou institucional, a sua não visibilidade para transpor o seu esquema em três momentos lógicos. Essas três instâncias de julgamento distribuíam a necessidade [desse esquema]: deve-se dar; deve-se aceitar; deve-se devolver. Uma versão não crítica do mesmo fato transportará essas mesmas modalidades para a coisa, qualificada, por seu turno, como devendo ser dada, aceita e devolvida. Ora, uma teoria indígena, notava Mauss, confere ao objeto do dom uma força (o bau) que o conduz no circuito da troca e o torna coativo. Relendo e prefaciando o Ensaio sobre o dom, Lévi-Strauss destacou esse kantismo latente. Ocorreu a Mauss o fato de não ter tirado vantagem de sua própria descoberta, de ter deixado para Malinowski [o privilégio] de dar a fórmula funcional da troca e ao próprio Lévi-Strauss o de dar a expressão não modalizada das Estruturas elementares do parentesco. Além disso, quando Lévi-Strauss redefiniu o fenômeno social total pela inclusão de seu observador, ele fazia uma oferta mais alta [surenchère] que a do criticismo. Se, por um lado, ele o descartava, evidentemente, por um outro lado, dava-lhe a versão generalizada, quer

212 Somanlu, ano 3, n. 1/2, jan./dez. 2003 
dizer, liberada dessa estrutura de juízo que havia valido a Kant seu sucesso, mas também o fechamento de seu sistema e brevemente seu esgotamento ${ }^{16}$. Como toda experiência, a experiência etnográfica é um processo de dupla alienação de si e de subjetivação do heterogêneo ${ }^{17}$. Ele dá-se nas condições em que a coisa é possível, quer dizer, pelo viés de propriedades psicofisiológicas latentes e inconscientes, e das expressões simbólicas em que os homens se encontram. A capacidade de aceder ao simbolismo precede o social; e, sobre este ponto, LéviStrauss liberava a escola durkheimiana de sua hipótese mais carregada: a das representações coletivas. A aprendizagem no seio de uma sociedade não difere, em essência, da aprendizagem de uma outra sociedade, quando até mesmo esta última [aprendizagem] encontraria mais cedo seu limite e pagaria, com este alto preço, o privilégio de ter tomado consciência de suas operações. "A observação sociológica, condenada, parece, pela intransponível antinomia que liberamos [...], dela escapa graças à capacidade do sujeito de objetivar-se indefinidamente, quer dizer (sem jamais chegar a abolir-se como sujeito), de projetar para o exterior frações sempre decrescentes de si”'18. Este arruinamento do kantismo, a pesquisa de outros suportes simbólicos que não aqueles privilegiados pelo helenismo e retomados como tais por Kant, tudo isso se tornará claro quando Lévi-Strauss revelar as operações de um Pensamento selvagem, de um pensamento sem escritura, mas, por isso mesmo, exercitado em simbolismos aderentes. Ficará visível, então, que a bifurcação escolhida pelos gregos, a inscrição das qualidades em uma estrutura discursiva consciente do regime de suas articulações, por mais preciosa, fecunda e nossa que ela tenha sido, não tinha qualquer necessidade. Nem esta opção nem seu destino fenomenológico aboliram o que haviam descartado. A via das máscaras, plena dos pré-requisitos estabelecidos nas Mitológicas, transportará para outros substratos simbólicos, pratos rituais, máscaras, placas de cobre e mitos, toda a matéria ameríndia do Ensaio sobre o dom.

\footnotetext{
16 'Se Mauss havia podido conceber o problema do juízo de outra forma que não nos termos da lógica clássica, e formulálo em termo da lógica das relações, então, com o próprio papel da cópula, seriam arruinadas as noções que têm lugar na argumentação' ('Introdução à obra de Marcel Mauss', Sociologia e antropologia, p. 11).

17 'Assim, a apreensão (que só pode ser objetiva) das formas inconscientes da atividade do espírito, conduz, da mesma forma,

à subjetivação' (lbid., p. 31).

18 'Introdução à obra de Marcel Mauss', Sociologia e antropologia, p. 29.
} 
Não se tratava, portanto, de criticar o criticismo, mas de reconhecer suas razões, seus meios e seu preço. Uma vez que estes estiverem identificados, poder-seá evitar o caráter fechado [do criticismo]. Estava claro que as fórmulas do juízo de experiência se encontravam ameaçadas de solipsismo, ou já devolvidas a seu simples protocolo jurídico, uma vez que as ciências matemáticas e naturais lhe haviam retirado suas operações. Mas, sobretudo, chegou o momento de renunciar a um princípio de adequação, sancionado pela equação entre as condições do objeto da experiência e as da experiência do objeto. Gerando apenas por si mesma o desencantamento do mundo, a experiência necessitava cimentar sua legitimidade, ainda que esta viesse a ser o complemento de uma teologia moral sem sacramentos e de uma razão prática sem obras nem retribuições. Em face do que a troca e o fenômeno social total teriam oferecido a ocasião de identificar um processo de subjetivação que a inteligência etnográfica deveria levar a seu ponto de elucidação. Eis aí um processo que Mauss havia, sem dúvida alguma, esboçado em sua história antropológica da pessoa, mas que ele havia confiado a esta alta elaboração do helenismo que foi o estoicismo. Seria necessário que ele culminasse na consciência transcendental e na filosofia de Fichte? Subjetivação, o termo havia sido adiantado por Claude Lévi-Strauss, e sem ter sido, então, comentado de outra forma. Doravante, dever-se-á ter, conjuntamente, duas fórmulas: a das Mitológicas, dizendo que, para conhecer o homem, é preciso desfazêlo, quer dizer, reabrir-lhe as possibilidades, e o processo de alienação e de subjetivação que está no coração de todo conhecimento filosófico. Portanto, não era apenas o helenismo como cultura que se encontrava reduzido à sua singularidade. Tornava-se menos convincente a escolha kantiana de uma operação lógica fixada pelo helenismo quando era necessário aceder à modernidade das ciências. A etnografia nasceu precisamente quando as ciências e as artes renunciaram, com toda evidência, à adequação, aos procedimentos miméticos e às traduções proposicionais: quer dizer, quando a fenomenologia entrou em seu luto.

\section{A conquista do concreto}

A lição dos etnólogos não retornava à filosofia como um modelo a seguir ou um convite à demissão: ela a incitava a reconhecer suas próprias opções, a confessar

214 Somanlu, ano 3, n. 1/2, jan./dez. 2003 
que sua legitimidade havia danificado seus motivos e que seus interditos cediam a outras virtualidades. Só veríamos melhor o preço da pesada herança do criticismo da qual nem a versão ostensiva apresentada pela exposição kantiana, nem a versão regressiva dos neokantianos podiam mais ser satisfatórias. Entretanto, nenhum esforço havia sido empregado [para chegar-se a tal situação] pelos filósofos. Merleau-Ponty havia querido renovar a primeira, partindo da psicologia da percepção. Dez anos mais tarde, Jules Vuillemim explicitará rigorosamente a versão regressiva, a transcrição das funções newtonianas nas sínteses do juízo de experiência ${ }^{19}$. Mas nem um nem outro produziram sua extensão ou sua substituta. Nada poderia fazê-lo. Nem a ambigüidade sistemática da Fenomenologia da percepscão, pela qual Merleau-Ponty tentava aceder à história sustentando uma fenomenologia pela outra, a de Husserl pela de Hegel. Nem o acento colocado no uso criticista das sínteses matemáticas e dinâmicas. Kant limitara o gênero dizendo em uma só frase a perfeição e o acabamento de sua lógica, quer dizer, em que limite se faria a repartição das matemáticas newtonianas nos momentos do juízo. Posteriormente, outros matemáticos haviam passado contrato com uma outra física. O esforço husserliano para repovoar a intuição com novas essências vividas, mas sempre apresadas por uma cláusula de preempção pela categorialização que as declara, refluía sobre a margem da narração, sobre esse núcleo declarativo inexorável de uma transcrição fenomenológica da experiência. Faltavalhe libertar-se do criticismo, uma vez reconhecido esse nó transcendental em que se encontram uma operação de conhecimento, uma consciência singular e uma produção de objetividade.

Nada era mais insistente, nos anos de pós-guerra, que o propósito de aceder a uma realidade concreta que continuava aguardando seus desvios e suas formas. Propósito, mas não ainda programa. Ocorrera, desde o século 19, um ultrapassamento pela literatura, alguma coisa como uma nova experiência tramada no encontro dos fatos e da maneira de dizê-los. Nem Sartre nem Merleau-Ponty o omitiram. Mas, em face de uma literatura ainda pensada no cone das possibilidades abertas pela infinita variação dos modos da narração, a filosofia podia manter sua serenidade. Era mais inquietante [o fato de] que, entre a virada do século e seus primeiros decênios,

${ }^{19}$ Física e metafísica kantiana, 1955. 
as ciências matemáticas e físicas haviam adquirido uma autonomia que nenhuma revolução copernicana poderia reinscrever nas possibilidades de uma fenomenologia. Podia-se, então, conceber duas saídas filosóficas. Ou, bem, estigmatizar a crise das ciências que recusavam a redução criticista e, dizia-se na época, vertiam na técnica. Encarregavam-se os filósofos de definir uma nova experiência. Eles pediriam muito à terceira Crítica kantiana e, muito em breve, mais ao gênio que ao gosto, ao sublime que ao belo. Ou, bem, pensar, hipótese inversa, que as ciências, doravante, não têm necessidade alguma de legitimar-se por um processo de fundamento sancionado pela experiência possível, que uma aprendizagem compensava o apelo às operações transcendentais, que a matemática vela pela sua conceptualidade, define sua lógica por uma parte dela mesma, cria sua metalógica, admite sua própria abertura e, enfim, não antecipa sua totalidade nem seu futuro. Que ela resolve sua modernidade com "os meios ordinários da disciplina". Que a crise, se crise há, não se encontra aí. Que a crise é a do próprio entendimento ou do saber europeu. Mas, então, não haveria saída no saber da história e da sociedade antes de qualquer reforma do entendimento. Merleau-Ponty concluía com Max Weber que as ciências da sociedade não constituem sistema de par com sua natureza de Geisteswissenschaften ("ciências do espírito"), isto é, de par com sua vocação a deslocar as figuras do real. Restava encontrar nesta instabilidade (mowvance) e apesar das aparências do relativismo, a matéria de um novo realismo, e isto no próprio oco de um pensamento filosófico à beira da renúncia.

Foi aqui que atuou um conhecimento do social conduzido até o etnográfico. Lévi-Strauss havia feito, sob a organização categorial da experiência, um uso da qualidade não subordinada ao esquematismo das coisas. Ele havia reabilitado os poderes de inteligência, de simbolismo e de comunicação, ele revelou uma efetividade simbólica que não mobilizava nenhuma fenomenologia do movimento. E esta reatualização de possibilidades, não tocadas por aquela opção estoiciana que Mauss erguia, encontrava o movimento da pintura que habita todos os textos dos filósofos dessa geração - sem que as razões desse acontecimento fossem claras. Tratando da experiência etnográfica, Needham comparava-a a [experiência] do cego de nascença que ganhou a visão. Desprovido de toda referência, ele responde, às vezes, à experiência com uma nova cegueira, psíquica desta vez. Mas a operação de conhecimento que

216 Somanlu, ano 3, n. 1/2, jan./dez. 2003 
analisa Lévi-Strauss não é o tudo ou nada suposto do cego de nascença do qual se elimina a catarata. Ela põe em jogo capacidades inconscientes comuns, e precisamente as que a neurofisiologia contemporânea confirma. Ela também mostra que a expressão acompanha a percepção e que o simbolismo precede à troca - mesmo que este seja um simbolismo aderente sem o qual a troca é impensável, sem o qual ela se perderia em um processo puramente material. Nesta conta, a experiência onde se joga a possibilidade da etnografia como ciência seria, portanto, mais do que a do cego de nascença, a de $A$ educação sentimental. Ou seja, esta deflagração súbita de nosso teatro que, sem motivo, Flaubert faz coincidir com a da vida moderna; ou, ainda, a do tempo redescoberto, subitamente retomado com uma outra memória, fundamental e qualitativa, esta quarta dimensão que dizia Proust, e a qual ele havia apreendido nas pinturas de Cézane ${ }^{20}$. A experiência kantiana havia dessacralizado o mundo, e Weber dela tirava as conseqüências. Lévi-Strauss lhe reabria a qualificação.

Seria preciso recomeçar o processo simultâneo de alienação e de subjetivação em que se ensaiava o humanismo dos antropólogos. Ele não carregava doutrina alguma, nenhum retorno à origem, nem mesmo boas palavras sobre a troca e sobre o outro. Mas ele colocou sob uma lente de aumento o que poderia ser, se bem que ela já tenha sido tomada em sortimentos culturais e, portanto, na história, uma opção filosófica. Lição de microfilosofia, se quisermos, ele revelava um direito de realismo. Seria um retorno ao momento das Luzes? Talvez, mas desta vez a escolha seria antes d'Alembert que Kant.

\section{Liberar-se da origem}

Foi introduzindo uma série de monografias sobre alguns filósofos célebres, um título imposto pela coleção que patrocinava a obra, que Merleau-Ponty renuncia a esta história contínua que fora uma fenomenologia do espírito filosófico. Ele amarrava o comércio dos filósofos a obras sempre marcadas por suas opções e hesitações. A antropologia dava sem dúvida uma alternativa à dialética. Mas, sobretudo,

20 "0 tempo redescoberto", tal é também o título de um capítulo de 0 pensamento selvagem. 
Filosofia, antropologia:

o fim de um mal-entendido

ela afrouxava uma marcha [cheminement] tomada no a priori das dimensões do juízo. "É levando tudo isso em conta que a antropologia social se encaminha para um balanço do espírito humano e para uma visão do que ele é e pode ser"21.

Era necessário, então, encontrar essas questões que tinham desviado alguns filósofos da filosofia. Veio um momento, com efeito, em que as decisões pessoais cederam às exigências do conhecimento que elas solicitavam. Ora, esse momento, no qual Lévi-Strauss debate com Mauss, encontrava-se de facto interno à filosofia. Ele deslocara-se do social à troca, a seus modos e a seus suportes, das instituições aos gestos e práticas culturais em que elas se objetivam, das condutas aos simbolismos em que elas desenvolvem sua inteligência imanente. A prova do social só pode ser mental. "Nós jamais podemos estar seguros de ter atingido o sentido de uma função ou de uma instituição se nós não estivermos à altura de reviver sua incidência sobre uma consciência singular" ${ }^{\prime 2}$. Merleau-Ponty via nisso confirmar-se que os primeiros instantes de objetividade e de consciência, os simbolismos aderentes e não menos partilhados, aqueles que todos os outros pressupõem, são qualitativos, que as primeiras geometrias são qualidades de forma. Que os movimentos já são trajetos, que daí parte, faz-se e refaz-se toda consciência como expressão e como aprendizagem. ${ }^{23}$ Que a percepção não é um ponto de partida, mas a figura tardia e mínima para onde se transpõem os traços necessários e suficientes de uma fenomenologia. Que seu enunciado, em primeira ou em terceira pessoa, é um simbolismo entre outros. Uma tal vigilância, exercitada nesses suportes do conhecimento, foi tão decisiva quanto a virada lingüística da filosofia anglo-saxônica. Talvez tenha ocorrido de ele ter feito seu lugar como que antecipadamente. Marcel Mauss era lingüista tanto quanto filósofo. Merleau-Ponty notava, na Fenomenologia da percep̧ão e em termos curiosamente próximos de Wittgenstein, que a linguagem nada diz, de início, senão ela mesma. Recolocada na envergadura de uma atividade simbólica, ela não carregará mais, ou somente, a ocasião de aí indexar o criticismo. Ela fará valer sua capacidade de invenção, seu ser de partilha, sua capacidade de finalização e de transformação e seu componente de realismo. Desde de seu primeiro livro, Merleau-Ponty havia posto em axioma que

${ }^{21}$ De Mauss a Claude Lévi-Strauss, Signes, p. 157.

${ }^{22}$ Claude Lévi-Strauss, Introduction à l'oeuvre de Marcel Mauss, p. 26.

${ }^{23}$ Cf. Resumé de cours. 1952-1953.

218 Somanlu, ano 3, n. 1/2, jan./dez. 2003 
não existe qualquer linguagem efetiva que não retenha alguma coisa daquilo de que se fala. Ele jamais se desdisse.

Ensaiemos esta hipótese: as ciências humanas, conduzidas até o conhecimento etnográfico que deslocava a maneira e a natureza do saber europeu, e aos quais ele pertence, deslocaram, ao final, o limite da instância filosófica. Elas a haviam liberado do senso comum, não como opinião sensata e partilhada, mas como a operação natural/criticista que amarrava toda fenomenologia. Recolocada no movimento de invenção, a questão da origem não tinha mais sentido, e a filosofia que a gerenciara estava efetivamente despossuída. Como começa um saber? Como todo o resto, na hesitação. E ele se legitima extraindo uma sintaxe de sua singularidade, e um simbolismo que o introduz na rede das marchas racionais.

Lévi-Strauss, analisando e levando a seu termo a questão kantiana latente das durkheimianas tinha feito valer, contra a tábua lógica do criticismo, um outro Euríclides ventríloquo, uma voz que sempre se carrega consigo ${ }^{24}$. Ele reaplica, contra a instauração platoniciana do enunciado predicativo, o argumento do incontestável já aí [déjà la] que Platão havia usado para confundir Parmênides. Ele lembrava desta vez que o mundo distribui-se e exprime-se também em qualidades, sem protocolo de enunciação. Merleau-Ponty ainda aí se descobria confirmado quando ele tentava contornar um saber determinado sob a autoridade da experiência kantiana e desfazer uma operação fixada pelas escolhas do helenismo. Sua curva histórica encerrava agora o horizonte fenomenológico. Se a experiência kantiana era um compromisso para não se tocar mais na fenomenalidade dessacralizada do mundo, então a crise do entendimento se dizia do interior do kantismo. Contra a afasia filosófica que foi sua conseqüência, e da qual não se eximia Heidegger, Merleau-Ponty reabre a expressão - suporte e propósito ${ }^{25}$. E bastava esta conjunção para negar a língua universal - segundo fim do leibnizianismo do qual Kant dizia ter escrito a apologia. Foi, com efeito, no cercamento transcendental que a harmonia preestabelecida teve razão. A esfoliação dos simbolismos, a lista finita, mas aberta, de famílias heterogêneas de linguagens, reabria o direito de uma seletividade dos interesses filosóficos. Há,

${ }^{24}$ Cf. Platon, Sophiste, 252 c.

${ }^{25}$ Cf. Notes de cours 1959-1961, p. 147-148. 
neste domínio igualmente, circunstâncias e prioridades para um conhecimento engajado em um processo inacabado de alienação e de subjetivação. $\mathrm{O}$ que verossimilmente diziam os termos opacos do quiasma e da carne [chair] do mundo, que argumentam no último manuscrito de Merleau-Ponty ( $O$ visivel e o invisivel). Eles têm, entretanto, uma significação imediata, a de abrir uma sintaxe filosófica afastando a operação simples da subjetividade transcendental.

$\mathrm{Na}$ falta de um ponto transcendental que as unificaria por princípio, e uma vez que elas intervêm em uma história que perseguem sem jamais começá-la, MerleauPonty enumerava algumas experiências de pensamento fundamental, entre as quais a pintura e sua história. Uma vez posto, nas primeiras páginas de $O$ olho e o espirito que a superfície pintada vale como um mapa mental, e que Cézane pensa em pintura, Merleau-Ponty pôde colocar em evidência, e por contraste, a opção cartesiana. O preço do método foi delegar à mecânica providencial do animal-máquina uma experiência na qual faltaria a ordem das razões. Assim, buscando um pensamento matemático em que a geometria assume plena posse de sua capacidade de criar espaços de representação, Descartes afastava e liberava, com o mesmo golpe, outras possibilidades. Aquelas mesmas que a Dióptrica designava com uma simples alusão aos tenros cortes que vos fazem ver em alguns traços colinas e tempestades ${ }^{26}$. Ora, estas capacidades simbólicas, recolhidas pela água-forte ou a técnica do óleo, mantidas pela prática da câmera obscura, foram precisamente erguidas nessa Holanda onde Descartes fixara residência, no coração da cidade e longe do mundo. A pintura se reinventa, então, entre Amsterdã e Delft, onde planisférios, espelhos d'água, mapas, notas [relevés] de cidade e cores autônomas pensam-se, dizem-se e variam seus propósitos. Portanto, a pintura inscrevera seu devir inesperado e seu saber sobre a história ininterrupta de um simbolismo imemorial. Em Amsterdã, uma diversificação era consumida, contra a qual nada podia a equação transcendental do filósofo de Königsberg.

Sobre este caminho, a singularidade filosófica não renunciará à prova do conhecimento, por mais perturbadora de seus a priori e inacabada que ela seja. Não

${ }^{26}$ Cf. L'oeil et l'esprit, chap. III.

220 Somanlu, ano 3, n. 1/2, jan./dez. 2003 
há para ela recuo [repli] estritamente ético. O exercício espiritual, que ela também é, ainda é uma reforma do entendimento e um processo inacabado de subjetivação. Todo etnólogo, diz Lévi-Strauss, escreve alguma espécie de confissão. É preciso, também, entender d'Alembert, quando ele defendia a empresa dos Enciclopedistas: "suprimais o conhecimento, vós guardareis todos os vícios, e mais a ignorância".

\section{Referências}

DURKHEIM, É. Les formes élementaires de la vie religieuse. 2. ed. Paris: Alcan, 1925.

DURKHEIM, É.; MAUSS, M. De quelques formes primitives de classification. L'Année sociologique (1900-1902). Paris: Alcan, 1903.

KANT, E. Atnthropologie du point de vue pragmatique. Paris: Vrin, 1964.

LÉVI-STRAUSS, C. La Sociologie française. In: La sociologie an XIXe siècle. Paris: PUF. 1947.v. 2.

. Lapensée sauvage. Paris: Plon. 1962. (Obra dedicada à memória de Maurice Merleau-Ponty).

La voie des masques. Genève, Skira, 1975. (1re éd.). Paris: Plon, 1979.

MERLEAU-PONTY, M. Structure du comportement. Paris: PUF, 1942.

. Humanisme et terreur. Paris: Gallimard, 1947.

. Sens et non-sens. Paris: Nagel, 1948.

. Les aventures de la dialectique. Paris: Gallimard, 1953.

. L'oeil et l'esprit. Paris: Gallimard, 1961.

. Signe. Paris: Gallimard, 1969. 